\title{
Globalization: The Changing Views Of American College Students (2007 - 2010)
}

K. Morris (Moshe) Speter, Mercy College, USA

\begin{abstract}
The attitudes of college students toward globalization and outsourcing are an important indicator of future leaders' positions. Surveys conducted over the last four years provide an insight into the current situation and changes in attitudes over time. Today, there is a great deal (over 50\%) of concern among college students about the positive value of globalization and support for laws to outlaw outsourcing. This is a reflection of the current economic situation and might change. With a large (82\%) percentage of students still believing that the U.S. should embrace globalization, the future situation is yet to be determined.
\end{abstract}

Keywords: attitudes; college students; globalization; outsourcing; survey

\section{INTRODUCTION}

s we emerge from the most severe economic crisis since the Great Depression and unemployment at
a high level, many people in the United States are blaming "globalization" and "outsourcing" for the
loss of American jobs. Over the last three years, the United States has also witnessed two dramatic elections as Americans voted for change in 2008 and again in 2010.

At the end of the Republican administration in the beginning of 2008, a survey was conducted of college students, majoring in International Business, to understand their knowledge of, and attitudes toward, globalization, in general, and the North American Free Trade Area (NAFTA), in particular. At the end of 2008, after the election of Barack Obama as president and the Democratic Party taking control of Congress, a second survey was conducted. A third survey took place at the end of 2009 and a fourth at the end of 2010. At this point, some trends can be ascertained from the research and described in the following report.

\section{APPROACH}

The survey was implemented among a convenient sample of college students taking an International Business course in New York. Initially, the survey was also done with graduate students and at two locations (i.e. New York and Connecticut). With the small sample size (18-20 students per wave), doing a statistically significant analysis is problematic. However, after four surveys, definitive trends can be seen, correlated to the events occurring over the same time frame, and certain inferences drawn.

College students represent the future leaders in society. They will become social influencers, business managers, and political power brokers who will shape America's destiny in the times to come. Their knowledge of, and attitudes toward, globalization will affect not only America, but the entire world.

Globalization is "the act or process of globalizing: the development of an increasingly integrated global economy marked especially by free trade, free flow of capital, and the tapping of foreign labor markets". Outsourcing "the contracting out of a business function - commonly one previously performed in-house - to an external provider", particularly with respect to manufacturing jobs going to China, has also been a major issue with Americans. 
Outsourcing and globalization has helped China become the second largest economy in the world and the process will continue to happen irrespective of the U.S. The answer as to whether America participates in the process, or tries to oppose it, may be found in the results of the surveys conducted.

\section{FINDINGS}

Given the notoriety that the term globalization has had, and the fact that the students were taking an International Business course, it is not surprising that $100 \%$ of the respondents were aware of the term. Over the different waves, this represented a slight increase from $96 \%$ and $97 \%$ in the 2008 time frame. Interestingly, awareness of NAFTA has declined over time. From 100\% awareness in the beginning of 2008 to $90 \%$ at the end of 2008 , the rate declined to $88 \%$ in 2009 and $83 \%$ at the end of 2010. This may indicate a lessening of importance of NAFTA in the mindset of the American public. Furthermore, students felt less and less positive about NAFTA (90\% of those who heard of NAFTA in the beginning of 2008 to $72 \%$ at the end of 2010) over time. Their thoughts as to whether the U.S. should enter into more agreements like NAFTA also declined over the same time period, from 69\% at the beginning of 2008 to $62 \%$ in 2010.

With respect to outsourcing, the survey results were even more eye opening, particularly comparing 2010 to 2009. The number of students who thought that outsourcing was a good idea dropped from $70 \%$ in 2009 to $50 \%$ in 2010. Similarly, only 59\% in 2010 thought that the U.S. has benefited from outsourcing as compared to $72 \%$ in 2009. At the same time, the percent of students that thought "if they had the power they would stop U.S. companies from outsourcing" went from $27 \%$ in 2009 to $47 \%$ in 2010 . More alarmingly, students' support for laws outlawing outsourcing rose from $45 \%$ in 2009 to $53 \%$ in 2010 . Finally, the percent of students who would "embrace" globalization declined from a high of $100 \%$ in 2009 to $82 \%$ in 2010 as shown in Table 1.

Table 1: College Students Survey Responses (Percent)

\begin{tabular}{|c|c|c|c|c|}
\hline Year & $\mathbf{2 0 0 8}\left(\mathbf{1}^{\text {st }} \mathbf{Q}\right)$ & $\left.\mathbf{2 0 0 8} \mathbf{( 4}^{\text {th }} \mathbf{Q}\right)$ & $\mathbf{2 0 0 9}\left(\mathbf{4}^{\text {th }} \mathbf{Q}\right)$ & $\mathbf{2 0 1 0}\left(\mathbf{4}^{\text {th }} \mathbf{Q}\right)$ \\
\hline Aware of Globalization & 96 & 97 & 100 & 100 \\
\hline Aware of NAFTA & 100 & 90 & 88 & 83 \\
\hline Would Embrace Globalization & 75 & 80 & 100 & 82 \\
\hline Think NAFTA is a Good Idea & 90 & 82 & 71 & 72 \\
\hline Would Support Laws Outlawing Outsourcing & 41 & 54 & 45 & 53 \\
\hline Would Stop US Companies From Outsourcing & 53 & 39 & 27 & 47 \\
\hline
\end{tabular}

\section{CONCLUSIONS}

With over half of the respondents supporting laws that would outlaw outsourcing, supporters of globalization have to be worried. The lingering impact of the "Great Recession" and jobless recovery has turned the majority of students toward thinking about keeping jobs at home. The growth in China and India is blamed on the siphoning off of jobs from America. Even NAFTA, which is globalization on a regional scale, is viewed less and less favorably. For President Obama, who pushed hard for a South Korean-American bilateral free trade agreement, logical arguments and efforts in support of free trade may back fire.

As America will soon begin the campaign for the 2012 elections, there is one area that the supporters of globalization can hope to build on. A large percent of the students (82\%) still say we should embrace globalization. Though down from $100 \%$ at the end of 2009, the positive response is still a large enough base to build upon, especially if the economy continues to grow and more people become employed. 


\section{NEXT STEPS}

There are a number of steps for this longitudinal study to continue, including:

1. Implement a fifth wave among undergraduate international business students at the end 2011

2. Use non-International Business students as a sample for comparison

3. Add some questions as to economic/demographic profile of the sample

\section{AUTHOR INFORMATION}

Dr. Speter teaches primarily International Business and Marketing courses at Mercy College. He has taught Graduate (i.e. MBA) and Undergraduate courses at a number of different institutions (e.g. College of Mount Saint Vincent, Berkeley College, University of New Haven) for over 13 years. Previously to entering Academia, Dr. Speter had a 25 year business career with major corporations (e.g. GTE, ITT, Citicorp, and AT\&T) with responsibility for strategic planning for both domestic and international marketplaces

\section{REFERENCES}

1. Merriam Webster ONLINE.2005 by Merriam-Webster, Incorporated. http://www.Merriam-Webster.com.

2. Speter, Morris, Globalization, Free Trade and Outsourcing - A College Student's Perspective, Northeast Business \& Economic Association Thirty Fifth Annual Conference, Melville, NY, November 6-8 2008.

3. Speter, Morris. Globalization, Free Trade and Outsourcing - A College Student's Perspective Part II, Knowledge Globalization Conference, Knowledge Globalization Institute, Boston MA April 17-19, 2009.

4. Speter, Morris. Globalization, Free Trade and Outsourcing - A College Student's Perspective Part III, Journal of International Business, April, 2010.

5. Wikipedia.org/wiki/Globalization, Outsourcing. 


\section{NOTES}

